\title{
Large bowel fermentation of maize or sorghum-acorn diets fed as a different source of carbohydrates to Landrace and Iberian pigs
}

\author{
J. Morales ${ }^{1}$, J. F. Pérez ${ }^{1}$, S. M. Martín-Orúe ${ }^{1}$, M. Fondevila ${ }^{2}$ and J. Gasa ${ }^{1}$ \\ ${ }^{1}$ Departament de Ciència Animal i dels Aliments, Universitat Autònoma de Barcelona, 08193 Bellaterra, Spain \\ ${ }^{2}$ Departamento de Producción Animal y Ciencia de los Alimentos, Universidad de Zaragoza, M. Servet 177, \\ Zaragoza 50013, Spain
}

(Received 26 October 2001 - Revised 24 May 2002 - Accepted 2 July 2002)

\begin{abstract}
Twenty-four finishing pigs (twelve Iberian and twelve Landrace) were used in a growing and slaughtering experiment. Animals were fed two diets differing in their ingredients, maize (diet C) or sorghum-acorn (diet A). At an average weight of $107.0 \mathrm{~kg}$ pigs were slaughtered and hindgut digesta sampled to study the effect of breed and diet on large bowel fermentation. Flows of digesta to the hindgut compartment were estimated based on an indigestible flow marker $\left(\mathrm{Cr}_{2} \mathrm{O}_{3}\right)$ and were higher in Iberian than in Landrace pigs $(P<0 \cdot 001)$, and higher in animals fed diet $\mathrm{A}$ than diet $\mathrm{C}(P=0 \cdot 07)$. The higher flows in Iberian pigs were mainly associated with a higher voluntary feed intake $(3.50 v .2 .70 \mathrm{~kg} / \mathrm{d}, P<0.01)$ and lower ileal digestibility of NSP ( $-12 \cdot 8 v .47 \cdot 8, P<0 \cdot 01)$. Differences between diets were mainly associated with a lower ileal digestibility of starch from diet A $(89.2$ v. $96.9 \%, P=0.06)$, although no differences in the resistant starch content were observed in vitro. Fermentation of different carbohydrates through the large bowel showed that NSP-glucose had lower digestibility in Iberian than in Landrace pigs $(62.5$ v. $94.2 \%, P<0.001)$, but no differences were observed in starch, or other NSPfibre fractions (arabinose, xylose and galactose). The type and amount of carbohydrates reaching the large bowel were related to the diet but also to breed, and promoted differences in the fermentative activity associated with different volatile fatty acid patterns and changes in microbial enzymic activity.
\end{abstract}

Carbohydrates: Large bowel fermentation: Landrace pigs: Iberian pigs

The components of the diet that are poorly digested in the small intestine of swine provide a substrate for microbial growth that allows the animal to utilise part of the energy of these substrates, the bacterial fermentation products. The amount of energy so absorbed in the large bowel of pigs is not negligible and may contribute up to $25 \%$ of the maintenance energy requirements (Yen et al. 1991). However, energy derived from fermentation endproducts is utilised with lower efficiency than energy absorbed in the small intestine (Noblet et al. 1994), and may determine to some extent the energy values of digestible components. Among energy sources, carbohydrates are the most abundant form of energy in plant materials and, as such, are the most widely available source of energy for feeding single-stomached animals. Carbohydrates, which include low-molecular-weight sugars, starch and NSP, provide a heterogeneous substrate (Bach Knudsen, 1997). In most mixed diets, starch constitutes the main source of carbohydrates in the small intestine while NSP, commonly referred to as dietary fibre, are mostly known to escape digestion in the small intestine and are fermented to different extents by the caecal and colonic bacteria (Jensen, 2001).

However, some starchy foods may also increase hindgut fermentation (Anderson et al. 1981). In this regard, Englyst et al. (1982) identified a starch fraction in cornflakes, which was resistant to $\alpha$-amylase (EC 3.2.1.1.), now termed resistant starch (RS). In contrast to structural resistance of NSP to mammalian enzymes, resistance of starch occurs for a number of chemical, technological and physiological reasons (Gallant et al. 1992; Annison \& Topping, 1994). RS occurs for a number of reasons, which have been used for RS classification into three main types (Englyst et al. 1992): RS1 includes that trapped within whole plant cells and food matrices; RS2 comprises those granules from certain plants that are gelatinised

\footnotetext{
Abbreviations: Ad, adenine; Gn, guanine; PB, purine bases; RS, resistant starch; TT, transit time; VFA, volatile fatty acids.

* Corresponding author: Dr José F. Pérez, fax +34 93 5812106, email jfperez@quiro.uab.es
} 
poorly and hydrolysed slowly by $\alpha$-amylases; RS3 comprises retrograded starches. Thus, foregut starch digestion has been shown to be conditioned by physiological variables including chewing and individual variation in transit (Champ, 1992; Englyst et al. 1992). In this context, the swine digestive system may have an influence on the nutritive value of each energy source and especially the starch fraction.

The present study aims to evaluate the effect of breed on the fractional digestion of carbohydrates in the foregut and hindgut compartments. Two genetically distinct strains of pigs, Landrace, a breed improved for lean growth rate, and the indigenous Iberian pigs, traditionally fattened in field conditions, have been previously shown to differ in their ability to digest carbohydrate (Morales et al. 2001) and offer an opportunity to study animal factors conditioning digestion of starch and NSP in the large intestine. In order to promote variation of carbohydrates characteristics, animals were fed ad libitum two diets differing in their carbohydrate ingredients (maize $v$. sorghum and acorn). We studied the microbial fermentation by measuring different parameters of the microbial activity, such as the purine bases (PB) content and the enzymic carbohydrase activity, and the simultaneous carbohydrate disappearance and distribution of volatile fatty acids (VFA) and $\mathrm{pH}$ along the large intestine.

A preliminary account of part of the present study has been published (Morales et al. 2001; Pérez et al. 2001).

\section{Experimental methods}

The experiment was performed at the Experimental Unit of the Universitat Autònoma de Barcelona and received prior approval from the Animal Protocol Review of this institution.

\section{Animals and diets}

Twenty-four castrated male finishing pigs (twelve Landrace, twelve Iberian; mean body weight 88.4 (SD 6.4) $\mathrm{kg}$ ) were housed in eight pens (three animals/pen) in an environmentally controlled building. Replicates were randomly divided into two groups offered ad libitum a maize- (diet C) or a sorghum-acorn- (diet A) based diet in a $2 \times 2$ factorial and randomised complete block design. Ingredient and analysed nutrient contents of diets are presented in Table 1. Diet A was composed of sorghum $(275 \mathrm{~g} / \mathrm{kg})$ and decorticated acorns $(125 \mathrm{~g} / \mathrm{kg})$, the fruit of the Quercus genus, which replaced partially the maize content of diet C $(754 \mathrm{~g} / \mathrm{kg})$. Despite the differences in the ingredients, both diets contained similar amounts of NSP, starch and RS, as measured in vitro.

We reduced the shell proportion of ground acorns (up to $12 \%$ ) by rough grinding. Diets were equalised for shell and fatty acids content by incorporating isolated shells and olive oil in the maize-based diets. $\mathrm{Cr}_{2} \mathrm{O}_{3}$ was included $(1.5 \mathrm{~g} / \mathrm{kg})$ as an indigestible marker.

\section{Experimental protocol}

Pen feed intake and individual body weight were recorded every 2 weeks. Pigs were slaughtered at an average weight of $107.0 \mathrm{~kg}$ without previous fastening in a commercial slaughterhouse after $\mathrm{CO}_{2}$ stunning. The whole gut was immediately excised and caecum, colon (proximal, medium and distal) and rectum were ligated, removed and weighed. The intestinal contents were collected and homogenised quickly and samples preserved (on average within $20 \mathrm{~min}$ after slaughtering). Ileal digesta were sampled from a $300 \mathrm{~mm}$ length segment, approximately $100 \mathrm{~mm}$ anterior to the ileal-caecal junction. Caecal digesta samples were frozen in liquid $\mathrm{N}_{2}$ and stored at $-70^{\circ} \mathrm{C}$ until their analysis for microbial enzymic activities. Caecal, colonic and rectal digesta samples were also acidified with $\mathrm{H}_{3} \mathrm{PO}_{4}$ (approximately $4 \mathrm{~g}$ fresh weight $/ \mathrm{ml} 5 \%$ (w/w) $\mathrm{H}_{3} \mathrm{PO}_{4}, 1 \%(\mathrm{w} / \mathrm{w})$ mercuric chloride and 50-mm 3-methyl valerate as internal standard) and stored at $-20^{\circ} \mathrm{C}$ until their analysis for VFA concentration. The rest of the ileal, caecal, medium colonic and rectal digesta were freeze-dried and milled for their analysis for $\mathrm{Cr}$, carbohydrates and PB.

\section{Analytical procedures}

Chemical analyses of the diets and digesta were conducted according to the Association of Official Analytical Chemists (1984) for DM, ash, crude protein and fat, and according to Goering \& Van Soest (1970) for lignin.

Table 1. Composition and analysed nutrient content of the maizebased diet (diet C) and the sorghum-acorn-based $\operatorname{diet}(\operatorname{diet} A)$

\begin{tabular}{lcc} 
& Diet C† & Diet A† \\
\hline Ingredients $(\mathrm{g} / \mathrm{kg})$ & 754 & 376 \\
Maize & - & 275 \\
Sorghum & - & 125 \\
Semi-decorticated acorn & 197 & 195 \\
Soyabean meal & 15 & - \\
Acorn shell & - & 7 \\
Soyabean oil & 12 & - \\
Olive oil & 22 & 22 \\
Vitamin and mineral premix & & \\
Nutrient analysis (g/kg DM) & 161.9 & 171.9 \\
Crude protein & 52.4 & 53.3 \\
Crude fat & & \\
NSP & 65.2 & 65.5 \\
$\quad$ Glucose & 13.0 & 13.4 \\
$\quad$ Galactose & 19.4 & 16.6 \\
$\quad$ Xylose & 16.6 & 15.3 \\
Arabinose & 561.0 & 513.4 \\
Starch & 107.0 & 106.0 \\
Resistant starch & 14.4 & 18.2 \\
Lignin & 16.62 & 16.48 \\
Gross energy (MJ/kg) & & \\
& &
\end{tabular}

*Provided the following/(kg diet): $\mathrm{CaCO}_{3}, 7.1 \mathrm{~g} ; \mathrm{CaHPO}_{4}, 7.9 \mathrm{~g} ; \mathrm{NaCl}, 2.3 \mathrm{~g}$; vitamin $A, 2100 \mathrm{mg}$; vitamin $D_{3}, 43 \mathrm{mg}$; vitamin $E, 10 \mathrm{mg}$; vitamin $K_{3}, 1 \mathrm{mg}$; vitamin $B_{1}, 1 \mathrm{mg}$; vitamin $B_{2}, 4 \mathrm{mg}$; vitamin $B_{6}, 2 \mathrm{mg}$; vitamin $B_{12}, 20 \mu \mathrm{g}$; biotin, $10 \mu \mathrm{g}$; niacin, $18 \mathrm{mg}$; Ca-d-pantothenic acid, $10 \mathrm{mg}$; choline, $175 \mathrm{mg}$; Fe, 80 mg; Zn, $110 \mathrm{mg}$; Cu, $90 \mathrm{mg}$; Mn, $50 \mathrm{mg}$; Co, $0.1 \mathrm{mg}$; I, $1 \mathrm{mg}$; Se, $0.2 \mathrm{mg}$.

†Ethoxiquin ${ }^{\circledR}(150 \mathrm{mg})$ and Luctamold ${ }^{\circledR}(500 \mathrm{mg}) / \mathrm{kg}$ feed were added to both diets. 
Gross energy was determined by adiabatic calorimetry. Total starch and NSP fractions of feed and digesta samples were measured by the method of Theander (1991). Briefly, total starch was determined as glucose liberated after an enzymic incubation with thermostable $\alpha$-amylase (Sigma ref. A-4551) for $1 \mathrm{~h}$ at $100^{\circ} \mathrm{C}$, and amyloglucosidase (Sigma ref. A-3514; St Louis, MO, USA) for $4 \mathrm{~h}$ at $60^{\circ} \mathrm{C}$. NSP were precipitated with $80 \%(\mathrm{v} / \mathrm{v})$ ethanol $(1 \mathrm{~h}$ at $4{ }^{\circ} \mathrm{C}$ ), and hydrolysed with sulfuric acid, using myoinositol as internal standard. RS was measured by the method of Berry (1986) modified by Champ (1992) as the part of starch not hydrolysed by incubation with $\alpha$-amylase for $16 \mathrm{~h}$ at $37^{\circ} \mathrm{C}$. Hydrolysis products were extracted in $80 \%$ (v/v) ethanol and discarded. RS was then made soluble with 4-M KOH and hydrolysed with amyloglucosidase for $90 \mathrm{~min}$ at $65^{\circ} \mathrm{C}$. Monosaccharides released from total and resistant starch, and NSP were analysed as alditol acetates by GLC. $\mathrm{Cr}_{2} \mathrm{O}_{3}$ concentration in feed and digesta was determined by atomic absorption spectrophotometry following the method of Williams et al. (1962).

$\mathrm{PB}$ (adenine (Ad) and guanine $(\mathrm{Gn})$ ) in digesta samples (40 mg) were determined by HPLC (Makkar \& Becker, 1999), after their acid hydrolysis with $2 \mathrm{ml} 2$-M-perchloric acid at $100^{\circ} \mathrm{C}$ for $1 \mathrm{~h}$, including $0.5 \mathrm{ml} 1-\mathrm{mM}$ allopurinol as internal standard. The microbial enzymes were extracted from the caecal contents by hydrolysis with lysozyme (Silva et al. 1987), harvested from the supernatant fraction after centrifugation at $23000 \mathrm{~g}$ for $15 \mathrm{~min}$, and kept frozen $\left(-20^{\circ} \mathrm{C}\right)$ until their analysis, in less than a month. Polysaccharidase activity of the enzyme extract was measured according to the method of Nelson-Somogyi (Ashwell, 1957) against carboxymethylcellulose (Sigma ref. C8758; carboxymethylcellulase activity), xylan from oat spelts (Sigma ref. X-0627; xylanase activity), soluble starch from potato (PANREAC 121096; Barcelona, Spain; amylase activity) and waxy starch from maize (Sigma ref. S-9679; amylopectinase activity). The activity of the enzymic extract was expressed as nmols of neutral sugars released $/ \mathrm{ml}$ extract per min and referred either to the dry weight of digesta (total enzymic activity) or the
PB content (bacterial enzymic activity). VFA concentration in deproteinised digesta was determined by GLC, following the method proposed by Jouany (1982).

\section{Calculations and statistical analysis}

Apparent digestibility along the intestine (ileum, caecum, intermediate colon and rectum) and daily flow of neutral sugars and PB in gastrointestinal segments were calculated by the marker $(\mathrm{Cr})$ ratio method. In particular, the daily flow of a nutrient through the ileum, caecum or colon was calculated as the ratio between concentrations of nutrient and $\mathrm{Cr}$ in digesta, multiplied by $\mathrm{Cr}$ intake/d. Caecal and colonic transit time (TT) were calculated as the mass of $\mathrm{Cr}$ present in the organ divided by $\mathrm{Cr}$ intake (Goodlad \& Mathers, 1987). Data were subjected to ANOVA, and a Tukey follow-up test was used for comparisons of means using the general linear model available in Statistical Analysis Systems statistical software package version 6.11 (SAS Institute, Cary, NC, USA) for a factorial arrangement of treatments. A two-tailed $P$ value of $<0.05$ was considered significant.

\section{Results}

Food intake and carbohydrates flow to the large bowel

Mean voluntary intake of Iberian pigs was significantly higher $(P=0.004)$ than that of Landrace $(3497 v .2699 \mathrm{~g}$ $\mathrm{DM} / \mathrm{d}$; Table 2), but no differences were observed between experimental diets. Iberian pigs also showed higher flows of carbohydrates to the large intestine, with a tendency for glucose $(122.1$ v. $63.2 \mathrm{~g} / \mathrm{d} ; P=0 \cdot 10)$, and significantly for galactose $(54.0$ v. $26.5 \mathrm{~g} / \mathrm{d} ; P=0.003)$ and arabinose + xylose $(198.2 v .81 .6 \mathrm{~g} / \mathrm{d} ; P=0.001)$ contained in the NSP, although not significantly for starch $(139.9$ v. $90.4 \mathrm{~g} / \mathrm{d}$; $P=0.45$ ). Between diets, diet A tended to promote a higher amount of starch entering the large intestine than diet $\mathrm{C}(174.3$ v. $56 \cdot 0 \mathrm{~g} / \mathrm{d} ; P=0.08)$.

Hindgut digesta contents (i.e. caecum + colon) were

Table 2. Voluntary feed intake, daily flows to the hindgut of starch and NSP fractions, digesta content and transit time in caecum and colon of Landrace and lberian finishing pigs fed a maize-based diet (diet C) or a sorghum-acorn-based diet (diet A) $\dagger$

\begin{tabular}{|c|c|c|c|c|c|c|c|c|}
\hline & \multicolumn{2}{|c|}{ Landrace } & \multicolumn{2}{|c|}{ Iberian } & \multirow[b]{2}{*}{ SE } & \multicolumn{3}{|c|}{ Probability } \\
\hline & Diet C & Diet A & Diet C & Diet A & & $P$ Breed & $P$ Diet & $P$ Breed $\times$ diet \\
\hline $\begin{array}{l}\text { Feed intake }(\mathrm{g} / \mathrm{d}) \\
\text { Daily flows to the hindgut }(\mathrm{g})\end{array}$ & 2626 & 2771 & 3461 & 3532 & $199 \cdot 0$ & ** & NS & NS \\
\hline $\begin{array}{l}\text { Starch } \\
\text { NSP }\end{array}$ & $31 \cdot 3$ & 149.5 & $80 \cdot 7$ & $199 \cdot 1$ & $66 \cdot 71$ & NS & 0.08 & NS \\
\hline $\begin{array}{l}\text { Glucose } \\
\text { Arabinose }+ \text { xylose } \\
\text { Galactose }\end{array}$ & $\begin{array}{l}45 \cdot 8 \\
73 \cdot 1 \\
24 \cdot 4\end{array}$ & $\begin{array}{l}80 \cdot 7 \\
90 \cdot 2 \\
28 \cdot 6\end{array}$ & $\begin{array}{r}97 \cdot 1 \\
209 \cdot 8 \\
45 \cdot 5\end{array}$ & $\begin{array}{r}147 \cdot 2 \\
186 \cdot 5 \\
62 \cdot 5\end{array}$ & $\begin{array}{r}35.49 \\
25 \cdot 57 \\
8.30\end{array}$ & $\begin{array}{l}0.10 \\
\star \star \star \\
\star \star\end{array}$ & $\begin{array}{l}\text { NS } \\
\text { NS } \\
\text { NS }\end{array}$ & $\begin{array}{l}\text { NS } \\
\text { NS } \\
\text { NS }\end{array}$ \\
\hline $\begin{array}{l}\text { Digesta content }(\mathrm{g}) \\
\text { Caecum } \\
\text { Colon }\end{array}$ & $\begin{array}{r}257 \\
1882\end{array}$ & $\begin{array}{r}412 \\
2382\end{array}$ & $\begin{array}{r}213 \\
1442\end{array}$ & $\begin{array}{r}231 \\
1251\end{array}$ & $\begin{array}{r}61 \cdot 7 \\
220 \cdot 7\end{array}$ & $\stackrel{*}{*}$ & $\begin{array}{l}\text { NS } \\
\text { NS }\end{array}$ & $\begin{array}{l}\text { NS } \\
\text { NS }\end{array}$ \\
\hline $\begin{array}{l}\text { Transit time }(\mathrm{h}) \\
\text { Caecum } \\
\text { Colon }\end{array}$ & $\begin{array}{r}1.29 \\
21.89\end{array}$ & $\begin{array}{r}1.59 \\
16 \cdot 87\end{array}$ & $\begin{array}{r}0.81 \\
11 \cdot 24\end{array}$ & $\begin{array}{l}0.66 \\
4.76\end{array}$ & $\begin{array}{l}0.260 \\
1.678\end{array}$ & $\stackrel{*}{*}$ & $\underset{* *}{N S}$ & $\begin{array}{l}\text { NS } \\
\text { NS }\end{array}$ \\
\hline
\end{tabular}

NS, $P>0.10 ;{ }^{*} P<0.05,{ }^{* *} P<0.01,{ }^{* * \star} P<0.001$

†For details of diets and procedures, see Table 1 and p. 490. 
significantly higher $(P<0.01)$ in Landrace $(2139$ and $2794 \mathrm{~g}$ ) than in Iberian pigs (1655 and $1482 \mathrm{~g}$ ) fed diet C and diet A, respectively (Pérez et al. 2001). No significant differences were observed between diets. TT in the large bowel was significantly higher in Landrace than Iberian pigs $(P<0.001)$ and with diet $\mathrm{C}$ than $\operatorname{diet} \mathrm{A}(P=0.018)$, averaging 23.2 and $18.5 \mathrm{~h}$ in Landrace and 12.1 and $5.4 \mathrm{~h}$ in Iberian pigs fed diet $\mathrm{C}$ and $\mathrm{A}$, respectively.

\section{Neutral sugars fermentation}

Fig. 1 shows the fractional digestibility (\%) through the large bowel compartment of starch and the main NSP constituents: glucose; galactose; xylose + arabinose. Significant differences were observed in the fractional digestibility of individual carbohydrates as affected by the breed or diet. Specifically, starch of diet A was less digested in the small intestine than that of diet $\mathrm{C}(89.2$ v. $96.9 \%$; $P=0.06$ ); no differences were observed between breeds. Differences between diets were progressively reduced along the large intestine compartment, and reached a complete digestion by the rectum with both diets. The small intestine digestibility of NSP-glucose was not significantly different between treatments. Average values were $67 \%$ in Landrace and $42 \%$ in Iberian pigs; between diets, mean values were 65 and $44 \%$ in animals fed diet $\mathrm{C}$ and $\mathrm{A}$, respectively. Large intestine fermentation increased NSPglucose digestion, but significant differences between
Landrace and Iberian pigs were still evident in the whole tract digestibility $(94.66$ v. $60.76 \% ; P<0.001)$. Fractional digestibility in the ileum of NSP-galactose and arabinose + xylose was significantly higher in Landrace than Iberian pigs, which unexpectedly presented negative values. Large intestine fermentation in the caecum compensated most differences. However, whole-tract digestibility of arabinose + xylose was still higher $(P<0.001)$ in Landrace (39.77) than Iberian (7.09) pigs.

\section{Purine bases and carbohydrase activities in large bowel digesta}

PB concentration in digesta is presented in Table 3. Compared with the middle colonic digesta, caecal digesta contained higher concentrations of PB (30-41 v. 7-11 $\mu \mathrm{mol} / \mathrm{g}$ $\mathrm{DM})$ and $\mathrm{Gn}$ :Ad $(1 \cdot 4-1.5$ v. $1 \cdot 1-1 \cdot 2)$. Significant differences in PB concentration were observed between breeds, being higher in the caecum in Landrace than Iberian (38.7 v. $32.1 \mu \mathrm{mol} / \mathrm{g} \mathrm{DM} ; P=0.047)$, and higher in the middle colon in Iberian than Landrace pigs (10.6 v. $8 \cdot 1 \mu \mathrm{mol} / \mathrm{g} \mathrm{DM}, P=0 \cdot 017)$. Differences in colonic digesta were significantly increased when $\mathrm{PB}$ were expressed on a daily flow basis, being higher in Iberian than Landrace $(7.8$ v. $5.2 \mathrm{mmol} / \mathrm{d} ; P=0.001)$ and in $\operatorname{diet} \mathrm{A}$ than $\operatorname{diet} \mathrm{C}$ ( 8.4 v. $4.6 \mathrm{mmol} / \mathrm{d} ; P=0.016$ ). Gn:Ad in the middle colon digesta were also significantly higher for Iberian than for Landrace pigs $(1 \cdot 18$ v. $1 \cdot 11 ; P=0 \cdot 05)$.
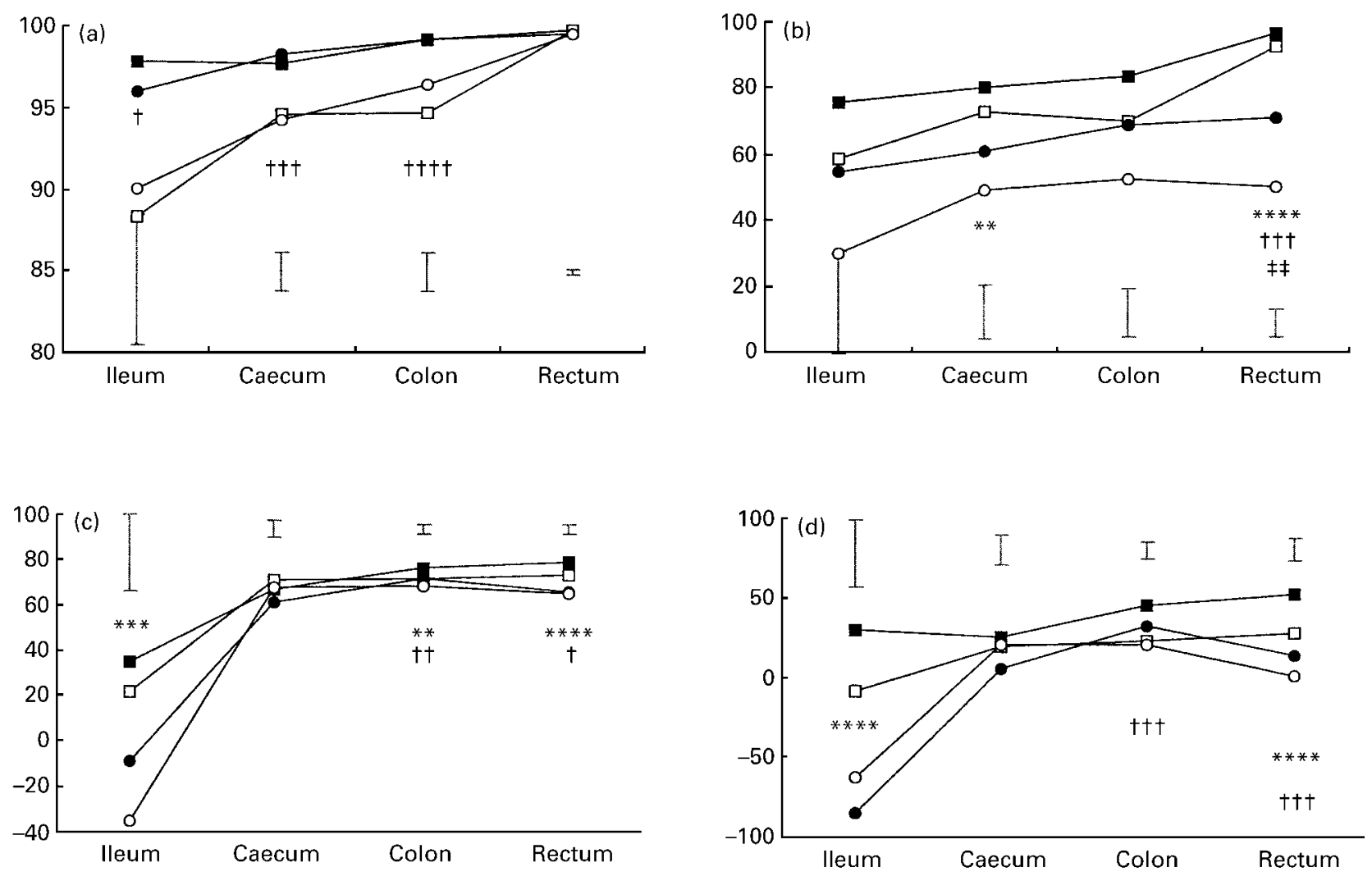

Fig. 1. Fractional digestibility of starchy glucose (a), NSP-glucose (b), NSP-galactose (c) and NSP-arabinose + xylose (d) in ileal, caecal, middle colonic and and rectal digesta of finishing pigs fed a maize-based diet ( $\mathbf{\square}$, Landrace; $\bullet$, Iberian) or a sorghum-acorn-based diet $(\square$, Landrace; $O$, Iberian). Standard errors are represented by vertical bars. ${ }^{\star \star} P<0.05,{ }^{* \star \star} P<0.01,{ }^{* \star \star \star} P<0.001$ (effect of breed); $\dagger P<0.10$, $\dagger † P<0.05, \dagger_{\dagger} P<0.01, \dagger_{\dagger \dagger \dagger} P<0.001$ (effect of diet); $\ddagger \ddagger P<0.05$ (effect of breed $\times$ diet). 
Table 3. Concentration and daily flow of purine bases, and guanine:adenine in caecal and middle colonic digesta of Landrace and Iberian pigs fed a maize-based diet (diet $\mathrm{C}$ ) or a sorghum-acorn-based diet $(\operatorname{diet} A) \dagger$

\begin{tabular}{|c|c|c|c|c|c|c|c|c|}
\hline & \multicolumn{2}{|c|}{ Landrace } & \multicolumn{2}{|c|}{ Iberian } & \multirow[b]{2}{*}{ SE } & \multicolumn{3}{|c|}{ Probability } \\
\hline & Diet C & Diet A & Diet C & Diet A & & $P$ Breed & $P$ Diet & $P$ Breed $\times$ diet \\
\hline \multicolumn{9}{|c|}{ Purine bases $(\mu \mathrm{mol} / \mathrm{g} D M)$} \\
\hline Caecum & $40 \cdot 7^{\circ}$ & $36 \cdot 7$ & 33.8 & $30 \cdot 3$ & 3.35 & * & NS & NS \\
\hline Colon & 7.5 & $8 \cdot 6$ & 10.5 & $10 \cdot 7$ & $1 \cdot 13$ & * & NS & NS \\
\hline \multicolumn{9}{|c|}{ Daily flow of purine bases $(\mathrm{mmol} / \mathrm{d})$} \\
\hline Caecum & $26 \cdot 7$ & $32 \cdot 6$ & $29 \cdot 1$ & 30.5 & 3.38 & NS & NS & NS \\
\hline Colon & 3.21 & $7 \cdot 22$ & 5.99 & $9 \cdot 64$ & $1 \cdot 10$ & ** & * & NS \\
\hline \multicolumn{9}{|c|}{ Guanine:adenine } \\
\hline Caecum & 1.44 & 1.46 & 1.49 & 1.47 & 0.040 & NS & NS & NS \\
\hline Colon & $1 \cdot 10$ & $1 \cdot 12$ & 1.18 & $1 \cdot 18$ & 0.039 & $*$ & NS & NS \\
\hline
\end{tabular}

NS, $P>0.10 ;{ }^{*} P<0.05,{ }^{* *} P<0.01$.

†For details of diets and procedures, see Table 1 and p. 490.

Mean values of total enzymic activities (nmol/g DM and min; Table 4) averaged 300 for carboxymethylcellulase, 838 for xylanase, 717 for amylase and 439 for amylopectinase. Iberian pigs showed higher values than Landrace pigs for carboxymethylcellulase, xylanase and amylopectinase $(P<0 \cdot 05)$. There was no dietary effect, except for a higher amylopectinase activity in Iberian pigs given diet A (interaction of breed $\times$ diet; $P=0.045$ ). Bacterial enzymic activities, as expressed on a $\mathrm{PB}$ ratio, better describe the specific activity of caecal microflora against carbohydrates. Significant differences were observed between breeds, showing the bacterial population in Iberian pigs to have a higher enzymic activity than in Landrace pigs. A higher amylopectinase activity was also observed $(P<0 \cdot 05)$ for the microbial population of animals fed diet A.

\section{Large bowel $\mathrm{pH}$ and volatile fatty acid concentrations}

Average $\mathrm{pH}$ values (Fig. 2) in ileal, caecal, middle colon and rectal digesta were $6 \cdot 1,5 \cdot 6,5 \cdot 8$ and $6 \cdot 2$, respectively, and no differences were observed between treatments.
VFA concentrations (Fig. 2) ranged from 95-200 $\mu \mathrm{mol} / \mathrm{g}$ digesta, reached the highest concentrations in the proximal (183.2) and medium (175.5) colonic digesta, and decreased progressively as digesta approached the rectum $(111.9 \mu \mathrm{mol} / \mathrm{g})$. Between treatments, concentrations of VFA tended to be lower in proximal colonic digesta of Iberian than in Landrace pigs (172.2 v. 194.2 $\mu \mathrm{mol} / \mathrm{g}$; $P=0 \cdot 06)$. No significant differences were observed in the rest of the large intestine.

Individual VFA profiles in the proximal and distal colon digesta are presented in Fig. 3. In the proximal colon, Iberian pigs showed higher propionate $(31.0$ v. 24.4; $P<0.001)$ and lower acetate $(56 \cdot 1$ v. $60 \cdot 1 ; P=0.040)$ percentages than Landrace. No significant differences were observed between diets. A defined pattern throughout the large bowel for acetate, propionate and butyrate was not observed. However, the percentage of propionate in Iberian pigs decreased through the colon as the percentage of acetate increased. Branched-chain VFA showed increasing values from proximal $(1.0 \%)$ to distal colon $(3.6 \%)$, where they were lower in Iberian than Landrace pigs $(P<0.05)$ and with diet A than diet $\mathrm{C}(P<0.05)$.

Table 4. Enzymatic acitivities (nmol glucose or xylose released/ml per min per g DM (total activity) or / $\mu \mathrm{mol}$ purine bases per min (bacterial activity)) of the caecal contents against carboxymethylcellulose, xylan, amylose and amylopectin of Landrace and lberian pigs fed on a maizebased diet (diet C) or a sorghum-acorn-based (diet $A) \dagger$

\begin{tabular}{|c|c|c|c|c|c|c|c|c|}
\hline & \multicolumn{2}{|c|}{ Landrace } & \multicolumn{2}{|c|}{ Iberian } & \multirow[b]{2}{*}{ SE } & \multicolumn{3}{|c|}{ Probability } \\
\hline & Diet C & $\operatorname{Diet} A$ & Diet C & Diet A & & $P$ Breed & $P$ Diet & $P$ Breed $\times$ diet \\
\hline \multicolumn{9}{|l|}{ Total activity } \\
\hline Carboxymethylcellulose & 290 & 170 & 395 & 344 & $64 \cdot 4$ & * & NS & NS \\
\hline Xylanase & 703 & 588 & 895 & 1164 & $154 \cdot 8$ & * & NS & NS \\
\hline Amylase & 635 & 583 & 741 & 909 & $137 \cdot 3$ & NS & NS & NS \\
\hline Amylopectinase & $193^{b}$ & $247^{b}$ & $265^{b}$ & $1052^{\mathrm{a}}$ & $197 \cdot 0$ & * & * & * \\
\hline Carboxymethylcellulose & $6 \cdot 9$ & $5 \cdot 1$ & $12 \cdot 5$ & $12 \cdot 7$ & $2 \cdot 02$ & ** & NS & NS \\
\hline Xylanase & $18 \cdot 4$ & $16 \cdot 2$ & $27 \cdot 1$ & 43.6 & $7 \cdot 41$ & ** & NS & NS \\
\hline Amylase & $15 \cdot 6$ & $16 \cdot 6$ & $25 \cdot 7$ & $28 \cdot 4$ & 5.49 & * & NS & NS \\
\hline Amylopectinase & 4.6 & 6.5 & $7 \cdot 2$ & $35 \cdot 0$ & $8 \cdot 15$ & * & * & 0.06 \\
\hline
\end{tabular}

${ }^{\mathrm{a}, \mathrm{b}}$ Group mean values with unlike superscript letters within a row were significantly different $(P<0.05)$.

NS, $P>0.10 ;{ }^{\star} P<0.05,{ }^{\star \star} P<0.01$.

†For details of diets and procedures, see Table 1 and p. 490. 

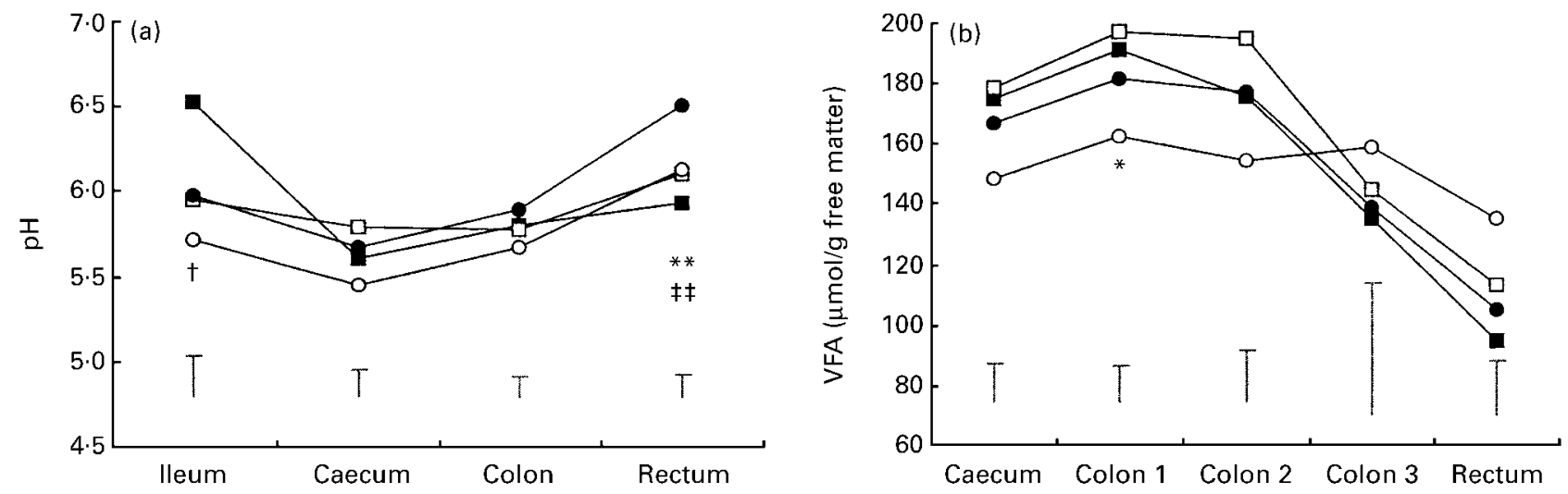

Fig. 2. $\mathrm{pH}$ (a) and volatile fatty acid (VFA) concentration (b) in ileal, caecal, colonic and rectal digesta of finishing pigs fed a maize-based diet ( $\mathbf{\square}$, Landrace; $\bullet$, Iberian) or a sorghum-acorn-based diet ( $\square$, Landrace; $\bigcirc$, Iberian). Standard errors are represented by vertical bars. ${ }^{\star} P<0.10,{ }^{\star \star} P<0.05$ (effect of breed); $\uparrow P<0.10$ (effect of diet); $\ddagger \ddagger P<0.05$ (effect of breed $\times$ diet).

\section{Discussion}

The extent of microbial fermentation in the large bowel of growing pigs may depend on dietary factors or the breed. In particular, dietary parameters other than the NSP content may reduce digestion in the small intestine, for example the content of RS (Champ et al. 1998), protein-starch interactions (Rooney \& Pflugfelder, 1986) or anti-nutritional factors (Lizardo et al. 1995). Moreover, comparison between breeds has also indicated differences in the feed intake and whole tract digestibility (Morales et al. 2001). In particular, Iberian pigs, an indigenous breed from the South-west Iberian Peninsula and traditionally fattened in field conditions, were compared in the present study with Landrace pigs to examine animal factors that might affect fore- and hindgut carbohydrate digestion.

\section{Digestibility measurement procedures}

Large amounts of digesta were collected from the caecum, colon and rectum after slaughtering, and fractional digestibility results obtained were consistent with other published results (Glitsø et al. 1998; Canibe \& Bach Knudsen, 2001). However, smaller intestine digesta samples were collected from the terminal ileum, which resulted in strange results, with negative values observed for galactose and arabinose-xylose fractions for Iberian pigs. It appears that the samples obtained from the ileum of slaughtered pigs were not representative of the total flow, probably due to phase separations between specific components of the digesta and the indigestible markers (Danfaer \& Fernandez, 1999). This phenomenon could be aggravated by gut contractions at slaughter, and were probably related to the high variability of the slaughter method (Prawirodigdo et al. 1998). Over the last 30 years, several studies have examined the digestion of NSP anterior to the caecum in pigs fitted with a cannula in the terminal ileum or by slaughter. However, none of these indicates the overall superiority of any one procedure (Donkoh et al. 1994). In particular, the negative digestibility of some NSP fractions has also been observed after cannulation (Jørgensen et al. 1996; Glits $\varnothing$ et al. 1998; Canibe \& Bach Knudsen, 2001). Cannulation has also received extensive criticism
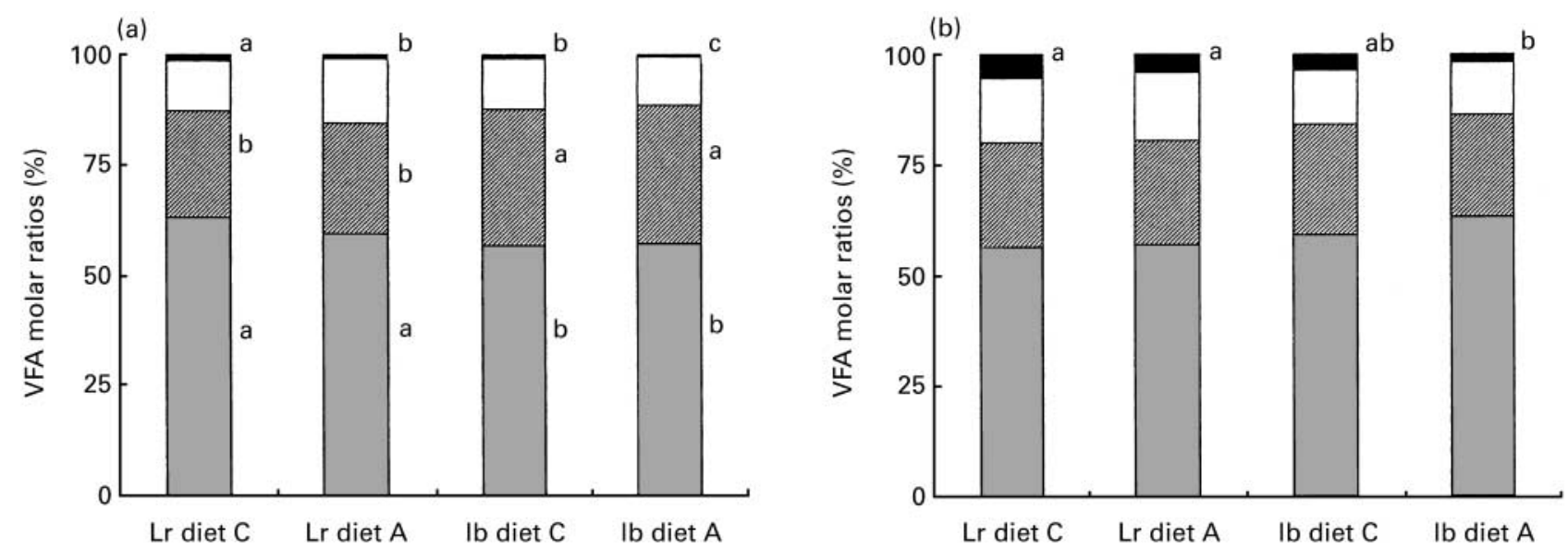

Fig. 3. Volatile fatty acids (VFA) molar ratios of acetate $(\square)$, propionate (级), butyrate $(\square)$ and branched-chain VFA ( $\square$ ) in proximal (a) and distal (b) colonic digesta of Landrace ( $\mathrm{Lr}$ ) and Iberian (Ib) pigs fed a maize-based diet (diet C) or a sorghum-acorn-based diet (diet A). $\mathrm{a}, \mathrm{b}, \mathrm{c} G$ roup means with unlike letters for a fatty acid fraction were significantly different $(P<0.05)$. 
revealing social concern about invasive procedures and the influence of surgery on the physiology of the animals (Canibe \& Bach Knudsen, 2001).

\section{Foregut digestion}

Our results indicate that a considerable proportion of the NSP-glucose $(54.7 v .77 .7 \%)$ and most starch $(93.1 v$. $99.7 \%$ ) disappeared in the upper intestine. Moreover, significant differences were observed between breeds, NSP digestion being higher in Landrace pigs. The disappearance of NSP in the upper intestine is caused by fermentation to VFA, depending on the composition and structure of the dietary fibre. Most $\beta$-glucans, approximately up to 0.4 of pentose sugars, such as xylose and arabinose, but no cellulose are digested before the terminal ileum (Fadel et al. 1989; Glitsø et al. 1998; Bach Knudsen \& Canibe, 2000). Marked differences between breeds observed in the present experiment could be due to longer TT and a higher bacterial density in the small intestine of Landrace pigs.

In both breeds higher amounts of starch from diet A escaped small intestine digestion (Fig. 1). Considering that no differences between diets in the RS content were observed in vitro, it appears that foregut digestion of starch involves variables not accounted for by the analytical procedures in vitro. The amount of starch escaping foregut digestion in vivo may depend on the extent of chewing, the rate of orocaecal transit, or the amount of starch ingested (Chapman et al. 1985; Englyst \& Cummings, 1990). It has also been suggested that starch resisting hydrolysis in vitro could be affected by the particle size after the grinding of feed samples compared with the particle size resulting from chewing in vivo (Englyst et al. 1992). Nevertheless, it is remarkable that no interactions were observed with the animal breed.

\section{Hindgut digestion}

Hindgut fermentation compensated most differences observed in the amount of carbohydrates escaping small intestine digestion (Fig. 1), except for Iberian pigs, which did not degrade NSP-glucose as efficiently as Landrace pigs. The fraction analysed as NSP-glucose is composed in cereals of cellulose (approximately two-thirds) and non-cellulosic glucose (one-third), mainly from $\beta$-glucans (Bach Knudsen, 1997). This indicates an average involvement of both components on the fractional digestibility of NSP-glucose. Theoretically, differences in the effective degradation of NSP could be associated with differences in the microbial activities or the time available for degradation. There is unlikely to be an inherent restriction on microbial degradation in Iberian pigs, due to the high enzymic activities observed in caecum digesta and bacteria (Table 4). On the other hand, the TT of digesta in the large bowel was much lower in Iberian than in Landrace pigs (Table 2). Many studies of plant cell-wall fermentation have established that fermentation is relatively slow (Van Soest et al. 1983) and variable among fibre sugars (Salvador et al. 1993), which means that variations in the TT might influence the extent of NSP digestion. Stephen et al. (1987) tested this hypothesis by modifying the TT of digesta in the large bowel of human volunteers. Reducing TT had little effect on the faecal output of the major pentose sugars, but increased the output of cellulose. Our results on NSP-glucose digestibility, partly influenced by cellulose, are consistent with those of Stephen et al. (1987).

\section{Microbial activity and fermentation parameters}

Although nucleic acids and PB are among the most commonly used naturally occurring microbial markers for rumen studies (Pérez et al. 1997; Makkar \& Becker, 1999), to our knowledge this is the first time that PB analysis has been used to quantify microbes in the large intestine. To obtain basic information on hindgut microbial proliferation, we assumed an average composition (324 $\mu \mathrm{mol} \mathrm{PB} / \mathrm{g}$ microbial crude protein) similar to bacteria isolated from rumen liquid samples (Pérez et al. 1997). Average microbial mass content estimated in digesta was $109 \mathrm{mg}$ microbial crude protein/g DM in the caecum, and significantly lower in the middle colon (29 mg microbial crude protein/g DM). Bacteria inhabiting the colon of single-stomached animals obtain their energy mainly from dietary sugars that escaped foregut digestion (Bergman, 1990). However, as fermentable carbohydrates decline along the colon, bacteria switch to the degradation of proteinaceous material and autolysis (Reid \& Hillman, 1999). Branched-chain VFA ratios also increased from the proximal to distal colon, being considered characteristic products of the fermentation of certain amino acids. PB in caecal digesta were lower in Iberian than in Landrace pigs, while the opposite occurred in the middle colon (especially on a daily flow basis), which reflects the higher extent of fermentation in the distal compartments of Iberian pigs. Concomitantly with the higher PB concentrations, significantly higher Gn:Ad were observed in caecal than in colonic digesta and in the middle colon of Iberian than in Landrace pigs. Differences in Gn:Ad may reflect changes in the bacterial community composition in the gastrointestinal tract (Apajalahti et al. 1998). In the present experiment, the caecal population of Iberian pigs showed higher total and bacterial enzymic activities than Landrace, which could reflect a selection of different species of bacteria by differences in the amount and type of substrates fermented and/or changes in the residence time of digesta (Table 2).

Endproducts of this fermentation have been described previously (Pérez et al. 2001). The results showed increases in caecal and proximal colon VFA content and a simultaneous fall in $\mathrm{pH}$. Butyrate molar responses were observed in caecal digesta of Landrace pigs fed diet A (breed $\times \operatorname{diet;} P=0.05$ ), while Iberian pigs fed $\operatorname{diet} \mathrm{A}$ showed a tendency for propionate to increase in the proximal colon and acetate in distal colon digesta. Many studies indicate that the nature and the amount of VFA produced are closely related to the type of sugars fermented (Salvador et al. 1993; Casterline et al. 1997). In vivo studies (Mathers et al. 1997; Topping et al. 1997) have provided evidence that starch fermentation leads to relatively higher molar ratios of butyrate, whereas Salvador 
et al. (1993) suggest that xylose is the most suitable of fibre sugars for the production of butyrate in vitro. Mathers \& Dawson (1991) collated data on caecal TT and molar proportion of butyrate from four separate studies and observed that caecal butyrate increased sharply when caecal TT decreased below about $0.75 \mathrm{~d}$. The present results in Iberian pigs conflict somewhat with those of Mathers \& Dawson (1991). It is remarkable that the caecum of Iberian pigs also fermented significantly higher amounts of arabinose, xylose and galactose, which could affect the higher propionate production. Mortensen et al. (1988) reported that the degradation of pentose sugars leads to the production of propionic acid. Salvador et al. (1993) also cited the involvement of glucose, arabinose and xylose, but suggested that the formation of propionic acid was less predicted by sugar disappearance than other VFA, such as acetate and butyrate.

The present study provides an opportunity to evaluate factors modifying the sites and amounts of carbohydrate fermentation in pigs, based on the comparison of two genetically distinct strains (Serra et al. 1998) when feeding on diets differing in their carbohydrate sources. Some fractions of NSP were shown to be fermented in appreciable percentages before reaching the large bowel, and differences between breeds may have been due to differences in TT. The type and amount of carbohydrates reaching the large bowel, related to the diet but also to breed, promoted differences in the microbial proliferation through the large bowel associated with different VFA patterns and changes in microbial activity.

\section{Acknowledgements}

This study has been supported by the CICYT-funded Project AGF98-0506.

\section{References}

Anderson IH, Levine AS \& Levitt MD (1981) Incomplete absorption of the carbohydrate in all-purpose wheat flour. New England Journal of Medicine 304, 891-892.

Annison G \& Topping DL (1994) Nutritional role of resistant starch: chemical structure vs physiological function. Annual Review of Nutrition 14, 297-320.

Apajalahti JHA, Särkilahti LK, Mäki BRE, Heikkinen JP, Nurminen PH \& Holben WE (1998) Effective recovery of bacterial DNA and percent-guanine-plus-cytosine-based analysis of community structure in the gastrointestinal tract of broiler chickens. Applied and Environmental Microbiology 64, 4084-4088.

Ashwell G (1957) Colorimetric analysis of sugars. In Methods in Enzymology, vol. 3, pp. 85-86 [SP Colowick and NO Kaplan, editors]. New York: Academic Press Inc.

Association of Official Analytical Chemists (1984) Official Methods of Analysis, 14th ed. Washington, DC: Association of Analytical Chemists.

Bach Knudsen KE (1997) Carbohydrate and lignin contents of plant materials used in animal feeding. Animal Feed Sciences and Technology 67, 319-338.

Bach Knudsen KE \& Canibe N (2000) Breakdown of plant carbohydrates in the digestive tract of pigs fed on wheat- or oat-based rolls. Journal of the Science of Food and Agriculture 80, $1253-1261$.

Bergman EN (1990) Energy contributions of volatile fatty acids from the gastrointestinal tract in various species. Physiological Reviews 70, 567-590.

Berry CS (1986) Resistant starch: formation and measurement of starch that survives exhaustive digestion with amylolytic enzymes during the determination of dietary fibre. Journal of Cereal Science 4, 301-314.

Canibe N \& Bach Knudsen KE (2001) Degradation and physicochemical changes of barley and pea fibre along the gastrointestinal tract of pigs. Journal of the Science of Food and Agriculture 82, 27-39.

Casterline JL, Oles CJ \& Ku Y (1997) In vitro fermentation of various food fiber fractions. Journal of Agricultural and Food Chemistry 45, 2463-2467.

Champ MM (1992) Determination of resistant starch in foods and food products: interlaboratory study. European Journal of Clinical Nutrition 46, Suppl. 1, s51-s61.

Champ MM, Molis C, Flourié B, Bornet F, Pellier P, Colonna P, Galmiche JP \& Rambaud JC (1998) Small-intestinal digestion of partially resistant cornstarch in healthy subjects. American Journal of Clinical Nutrition 68, 705-710.

Chapman RW, Sillery JK, Graham MM \& Saunders DR (1985) Absorption of starch by healthy ileostomates: effect of transit time and of carbohydrate load. American Journal of Clinical Nutrition 41, 1244-1248.

Danfaer A \& Fernandez JA (1999) Developments in the prediction of nutrient availability in pigs: a review. Acta Agriculturae Scandinavica 49, 73-82.

Donkoh A, Moughan PJ \& Smith WC (1994) Comparison of the slaughter method and simple T-piece cannulation of the terminal ileum for determining ileal amino acid digestibility in meat and bone meal for the growing pig. Animal Feed Science and Technology 49, 43-56.

Englyst HN \& Cummings JH (1990) Non-starch polysaccharides (dietary fiber) and resistant starch. In New Developments in Dietary Fiber. Physiological, Physicochemical, and Analytical Aspects, pp. 205-225 [I Furda and CJ Brine, editors]. New York and London: Plenum Press.

Englyst HN, Kingman SM \& Cummings JH (1992) Classification and measurement of nutritionally important starch fractions. European Journal of Clinical Nutrition 46, Suppl. 2, s33-s50.

Englyst HN, Wiggins HS \& Cummings JH (1982) Determination of non-starch polysaccharides in plant foods by gas liquid chromatography of constituents sugars as alditol acetates. Analyst 107, 307-318.

Fadel JG, Newman RK, Newman CW \& Graham H (1989) Effects of baking hulless barley on the digestibility of dietary components as measured at the ileum and in the feces of pigs. Journal of Nutrition 119, 722-726.

Gallant DJ, Bouchet B, Buléon A \& Pérez S (1992) Physical characteristics of starch granules and susceptibility to enzymatic degradation. European Journal of Clinical Nutrition 46, Suppl. 2, s3-s16.

Glits $\varnothing$ LV, Brunsgaard G, Højsgaard S, Sandström B \& Bach Knudsen KE (1998) Intestinal degradation in pigs of rye dietary fibre with different structural characteristics. British Journal of Nutrition 80, 457-468.

Goering HK \& Van Soest PJ (1970) Forage Fiber Analysis (Apparatus, Reagents, Procedures, and some Applications). Agricultural Handbook no. 379. Washington, DC: ARS and USDA.

Goodlad JS \& Mathers JC (1987) Digesta flow from the ileum and transit time through the caecum of rats given diets containing graded levels of peas. Proceedings of the Nutrition Society 46, 149A. 
Jensen BB (2001) Possible ways of modifying type and amounts of products from microbial fermentation in the gut. In Gut Environment of Pigs, pp. 181-200 [A Piva, KE Bach Knudsen and JE Lindberg, editors]. Nottingham, UK: Nottingham University Press.

Jørgensen H, Zhao XQ \& Eggum BO (1996) The influence of dietary fibre and environmental temperature on the development of the gastrointestinal tract, digestibility, degree of fermentation in the hind-gut and energy metabolism in pigs. British Journal of Nutrition 75, 365-378.

Jouany JP (1982) Volatile fatty acid and alcohol determination in digestive contents, silage juices, bacterial cultures and anaerobic fermentor contents. Science des Aliments 2, $131-144$.

Lizardo R, Peiniau J \& Aumaitre A (1995) Effect of sorghum on performance, digestibility of dietary components and activities of pancreatic and intestinal enzymes in the weaned piglet. Animal Feed Science and Technology 56, 67-82.

Makkar HPS \& Becker K (1999) Purine quantification in digesta from ruminants by spectrophotometric and HPLC methods. British Journal of Nutrition 81, 107-112.

Mathers JC \& Dawson LD (1991) Large bowel fermentation in rats eating processed potatoes. British Journal of Nutrition 66, 313-329.

Mathers JC, Smith H \& Carter S (1997) Dose-response effects of raw potato starch on small intestinal escape, large-bowel fermentation and gut transit time in the rat. British Journal of Nutrition 78, 1015-1029.

Morales J, Pérez JF, Baucells MD, Gasa A \& Gasa J (2001) Comparative digestibility and productive performances between Landrace and Iberian pigs fed on a corn- or a sorghumacorn-based diet. In Digestive Physiology in Pigs, chapter 63, pp. 227-229 [JE Lindberg and B Ogle, editors]. Oxon, UK: CABI Publishing.

Mortensen B, Holtug K \& Rasmussen HS (1988) Short-chain fatty acid production from mono- and disaccharides in a fecal incubation system: implications for colonic fermentation of dietary fiber in humans. Journal of Nutrition 118, 321-325.

Noblet J, Fortune H, Shi XS \& Dubois S (1994) Prediction of net energy value of feeds for growing pigs. Journal of Animal Science 72, 344-354.

Pérez JF, Balcells J, Guada JA \& Castrillo C (1997) Rumen microbial production estimated either from urinary purine derivative excretion or from direct measurements of ${ }^{15} \mathrm{~N}$ and purine bases as microbial markers: effect of protein source and rumen bacteria isolates. Animal Science 65, 225-236.

Pérez JF, Morales J, Baucells MD \& Gasa J (2001) An increased hindgut fermentation promoted major changes on the VFA profile but not on the total VFA concentration or the digesta contents. In Digestive Physiology in Pigs, chapter 62, pp. 224-226
[JE Lindberg and B Ogle, editors]. Oxon, UK: CABI Publishing.

Prawirodigdo S, Gannon NJ, van Barneveld RJ, Kerton DJ, Leury BJ \& Dunshea FR (1998) Assessment of apparent ileal digestibility of amino acids and nitrogen in cottonseed and soyabean meals fed to pigs determined using ileal dissection under halothane anaesthesia or following carbon dioxide-stunning. British Journal of Nutrition 80, 183-191.

Reid CA \& Hillman K (1999) The effects of retrogradation and amylose/amylopectin ratio of starches on carbohydrate fermentation and microbial populations in the porcine colon. Animal Science 68, 503-510.

Rooney LW \& Pflugfelder RL (1986) Factors affecting starch digestibility with special emphasis on sorghum and corn. Journal of Animal Science 63, 1607-1623.

Salvador V, Cherbut C, Barry JL, Bertrand D, Bonnet C \& Delort-Laval J (1993) Sugar composition of dietary fibre and short-chain fatty acid production during in vitro fermentation by human bacteria. British Journal of Nutrition 70, 189-197.

Serra X, Gil F, Pérez-Enciso M, Oliver MA, Vázquez JM, Gispert M, Día I, Moreno F, Latorre R \& Noguera JL (1998) A comparison of carcass, meat quality and histochemical characteristics of Iberian (Guadyerbas line) and Landrace pigs. Livestock Production Science 56, 215-223.

Silva AT, Wallace RJ \& Ørskov ER (1987) Use of particle-bound microbial enzyme activity to predict the rate and extent of fibre degradation in the rumen. British Journal of Nutrition 57, 407-415.

Stephen AM, Wiggins HS \& Cummings JH (1987) Effects of changing transit time on colonic microbial metabolism in man. Gut 28, 601-609.

Theander O (1991) Chemical analysis of lignocellulosic materials. Animal Feed Science and Technology 32, 35-44.

Topping DL, Gooden JM, Brown IL, Biebrick DA, McGrath L, Trimble RP, Choct M \& Illman RJ (1997) A high amylose (amylomaize) starch raises proximal large bowel starch and increases colon length in pigs. Journal of Nutrition 127, $615-622$.

Van Soest PJ, Jeraci J, Foose T, Wrick K \& Ehle F (1983) Comparative fermentation of fibre in man and other animals. In Fibre in Human and Animal Nutrition, pp. 75-80 [G Wallace and L Bell, editors]. Wellington, New Zealand: The Royal Society of New Zealand.

Williams CH, David DJ \& Iismaa O (1962) The determination of chromic oxide in faeces samples by atomic absorption spectrophotometry. Journal of Agricultural Science 59, 381-385.

Yen JT, Nienaber JA, Hill DA \& Pond WG (1991) Potential contribution of absorbed volatile fatty acids to whole-animal energy requirement in conscious swine. Journal of Animal Science 69, 2001-2012. 